\title{
PENDAMPINGAN KONSTRUKSI DAN OPERASIONALISASI SETNET BERDASARKAN KAJI TERAP SETNET DI JENEPONTO, SULAWESI SELATAN
}

\author{
Assistance of Sonstruction and Operationalization of Setnet Fishery Based on \\ The Results of The Experiment Applied in Jeneponto, South Sulawesi
}

\author{
Oleh: \\ Zarochman $^{1 *}$ \\ ${ }^{1}$ Balai Besar Pengembangan Penangkapan Ikan, Semarang

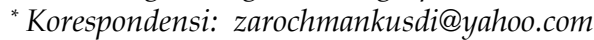

Diterima: 23 April 2013; Disetujui: 3 Juli 2013

\begin{abstract}
Operationalization setnet is the stage during setnet operation in waters coincided fish migration routes that meet the number of operating days per year that ensures continuous operation setnet. Assistance during construction continued for operationalization setnet to sustain operations through cooperation setnet technical guidance and management: preparation of backup setnet, care unit set-net, set-net operation, handling set-net catch and utilization of the catch setnet. Research methodology is studied arranging for trials setnet operation in 2012. Based on the results of experiment applied in Jeneponto has inspired a variety of information developed measures setnet fisheries management towards an increasingly comprehensive. Sustainability setnet operation by a group of fishermen setnet followed by an increase in the number of operating days and catch fish to be an important indication for continued development efforts.
\end{abstract}

Key words: days of operation, operationalization, setnet, the catch of fish

\begin{abstract}
ABSTRAK
Operasionalisasi setnet merupakan tahapan selama pengoperasian setnet pada perairan yang bertepatan rute migrasi ikan yang memenuhi jumlah hari operasi per tahun yang menjamin pengoperasian setnet secara berkelanjutan. Pendampingan konstruksi setnet diteruskan selama operasionalisasi setnet untuk menjaga keberlanjutan pengoperasian setnet melalui kerjasama pembinaan bidang teknis dan manajemen: penyiapan cadangan setnet, perawatan unit set-net, pengoperasian set-net, penanganan hasil tangkapan setnet dan pendayagunaannya. Metodologi penelitian adalah kaji terap selama uji coba pengoperasian setnet pada 2012. Berdasarkan hasil kaji terap setnet di Jeneponto menginspirasikan informasi berbagai langkah-langkah yang berkembang kearah manajemen perikanan setnet yang semakin komprehensif. Keberlanjutan pengoperasian setnet oleh kelompok nelayan setnet dengan diikuti peningkatan jumlah hari operasi dan hasil tangkapan ikan menjadi indikasi penting untuk diteruskan upaya pengembangannya.
\end{abstract}

Kata kunci: hari operasi, operasionalisasi, setnet, hasil tangkapan

\section{PENDAHULUAN}

Setnet tergolong perangkap berukuran besar dipasang menetap terus menerus, siang dan malam agar gerombolan ikan yang beruaya masuk kedalam kantong setnet. Dalam operasionalnya diperlukan keberlanjutan pengoperasian setnet dengan mempersiapkan kelompok 
nelayan setnet yang mampu menjamin keberlanjutan usaha perikanan setnet yang lebih maju dan mandiri dalam pengoperasian dan perawatan selanjutnya. Pengelolaan operasional setnet dilakukan kelompok nelayan yang bertanggung jawab atas keberlanjutan usahanya.

Implementasi kegiatan uji coba setnet di Jeneponto sejak tahapan pra-konstruksi hingga operasionalisasi: pemilihan tipe sebagai rancangan awal desain unit setnet, penyiapan desain dengan perhitungan dan pertimbanganpertimbangan konstruksi setnet, konstruksi, pemasangan, pengoperasian dan pengelolaan perikanan setnet. Adapun tujuannya: 1) merealisasikan desain unit setnet untuk siap dikonstruksi dan dipasang di perairan, 2) membentuk dan memberdayakan kelompok nelayan setnet siap mengoperasionalkan dan mengelola perikanan setnet, 3) kegiatan pendampingan dalam rangka operasionalisasi perikanan setnet yang berkelanjutan.

Semenjak tahun 2009, Pemerintah Indonesia cq Kementrian Kelautan dan Perikanan (BBPPI Semarang) telah memulai uji coba perikanan setnet di perairan Teluk Malasoro, dekat Pulau Libukan, Kabupaten Jeneponto, Sulawesi Selatan. Hingga akhir tahun 2012, sesuai MoU antara BBPPI Semarang dan Pemerintah Daerah Kabupaten Jeneponto, terus diupayakan pembinaan peningkatan kinerja operasionalisasi setnet melalui kegiatan pendampingan.

Kegiatan pendampingan yang dilakukan BBPPI selama tahun 2012-2013 meliputi tahapan monitoring dan evaluasi kinerja setnet selama operasionalisasi di lapangan, penyiapan implementasi pembinaan terhadap kelompok nelayan setnet dalam menjaga keberlanjutan pengoperasian setnet. Dari hasil evaluasi kinerja operasionalisasi setnet dilaksanakan perbaikan konstruksi setnet yang telah terpasang di Jeneponto hingga menyediakan kelengkapan komponen cadangan setnet untuk memenuhi kebutuhan dalam rangka peningkatan frekuensi pengoperasian setnet. Tolok ukur kinerja operasionalisasi setnet adalah didasarkan atas keberlanjutan dan frekuensi pengoperasian dalam setiap tahunnya. Oleh karena itu, pendampingan selama operasionalisasi setnet bertujuan meningkatkan operasional setnet dengan sasaran utama peningkatan jumlah hari operasi mencapai optimal setiap tahun.

\section{METODE}

Lokasi pengamatan operasional bertepatan tempat pemasangan setnet di Pulau Libukan, perairan Telauk Malasoro, Kabupaten
Jeneponto Sulawesi Selatan. Waktu pengamatan selama periode bulan Januari-Desember 2012.

Pendampingan dalam strategi pengembangan setnet merupakan bagian dari kegiatan tim manajemen setnet untuk meningkatkan nilai tambah dan usaha setnet berkelanjutan. Kegiatan pendampingan ujicoba setnet di Pulau Libukang, Jeneponto dilakukan dengan metode:

1) Memberikan konsultansi penyesuaian dimensi dan perbaikan konstruksi setnet terkait dengan penyesuaian kedalaman, penguatan kerangka dan penambahan kantong setnet.

2) Inventarisasi kebutuhan komponen cadangan dan perbaikan setnet hasil pengamatan langsung di lapangan. Dari hasil pemeriksaan dan wawancara dianalisa sesuai kebutuhan teknis perbaikan kinerja konstruksi setnet melalui pembuatan desain dan rincian spesifikasi penguatan kerangka dan modifikasi pembuatan jaring pada bagian badan dan penaju setnet.

3) Pengumpulan jurnal kegiatan harian selama setahun hasil kinerja selama pengoperasian dan data primer pengamatan langsung di lapangan, meliputi : identifikasi, pengukuran dan analisa komposisi kelompok ikan, penanganan hasil tangkapan dan pendayagunaannya.

4) Pengamatan kondisi lingkungan atau fenomena perairan di sekitar setnet dan identifikasi kebutuhan perawatan setnet serta kegiatan operasional lainnya untuk pengungkapan masalah sebagai umpan balik bagi peningkatan frekuensi operasi harian setnet.

Penelitian dilaksanakan di hatchery Bahari Desa Tanjung Pasir Kecamatan Teluknaga Kabupaten Tangerang Provinsi Banten dan di Laboratorium Jurusan Perikanan Faperta Untirta. Penelitian dilaksanakan pada bulan Juli hingga Oktober 2012.

Tahapan kerekayasaan konstruksi setnet dilakukan melalui tahapan penetapan desain konseptual, dilanjutkan desain awal dan desain rinci unit setnet. Desain konseptual dilandasi oleh adanya gagasan awal jenis setnet yang dipadukan adanya setnet yang dimodifikasi untuk disesuaikan dengan kondisi di Indonesia. Untuk menentukan pilihan setnet yang akan dikembangkan maka diperlukan studi banding dari beberapa jenis setnet. Penetapan desain konseptual dan awal meliputi pemahaman setnet untuk pemilihan tipe, perancangan penetapan desain dan konstruksi setnet. Dalam desain rinci ditetapkan dimensi setnet sesuai 
dengan pedoman MATSUNAGA dalam realisasi rancangan kerangka setnet seperti diperlihatkan pada Tabel 1. Bersamaan pengoperasian setnet dilakukan penyesuaian desain dan konstruksi. Penyesuaian desain mengikuti kedalaman perairan bagian badan setnet 20 meter, penyesuaian konstruksi kerangka berkantong dua dan penguatan kerangka.

\section{Pendampingan Selama Pengembangan Setnet}

Dalam sistem industrialisasi hulu perikanan setnet diperlukan penetapan lokasi setnet, penetapan unit setnet dengan sistem pengoperasiannya. Sejalan dengan ini dilakukan pemberdayaan kelompok nelayan untuk menjaga keberlanjutan operasional pengelolaan perikanan setnet dan peran pengawasan terhadap lingkungan perairan di sekitarnya.

Sistem produksi hilir pada perikanan setnet diperlukan penanganan ikan hidup dan segar mulai dari pengambilan ikan dan penempatan ikan dan penanganan ikan diatas kapal hingga penyiapan penjualan kepada para para pengumpul dan pembeli. Sistem penanganan ikan hasil tangkapanan setnet oleh kelompok ne-layan yang mengoperasikan setnet harus dijaga jaminan nilai jual yang baik. Oleh karena itu penerapan setnet menumbuhkan industrialisasi produk pangan dengan penanganan cepat berupa ikan segar dan hidup.

Pengembangan setnet dapat digambarkan dengan skema berupa model untuk mencapai sasaran yang mampu menjaga eksistensi setnet. Model pengembangan setnet ini berupa tim manajemen dan pendampingan ( $c 0$ management) untuk memanfaatkan sumber daya ikan peruaya dengan sarana unit setnet beriringan dengan implementasi proses industri perikanan setnet bagian hulu mulai pemilihan lokasi dan penetapan posisi setnet hingga pada bagian hilir yang mampu mengoperasikan setnet mencapai hasil yang optimal. Adapun sasaran yang dicapai adalah peningkatan nilai tambah dan keberlanjutan usaha perikanan setnet (Gambar 2).

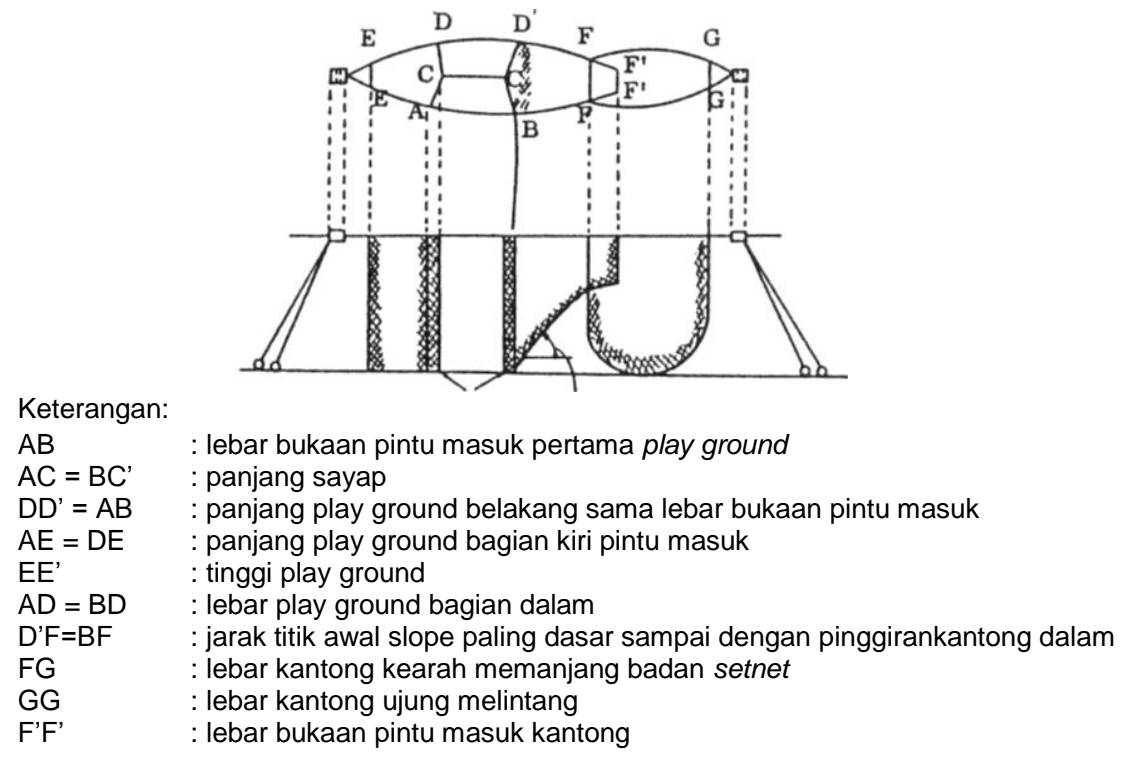

Gambar 1 Dimensi Otoshi-ami

Tabel 1 Penjelasan dimensi otoshi-ami (Gambar 1) sesuai dengan pedoman MATSUNAGA (1990)

\begin{tabular}{ll}
\hline \multicolumn{1}{c}{ BAGIAN JARING } & KETENTUAN TEKNIS \\
\hline Lebar bukaan pintu masuk play ground ( $A B)$ & $=100-150 \%$ \\
$A C$ or $B C^{\prime}$ ( Wing) & $30-35 \%$ \\
$D D^{\prime}=A B$ & $1,5-3 \mathrm{~d}^{*}$ \\
AE or DE & $80-100 \%$ \\
$\mathrm{E}$ E' & $80-100 \% \mathrm{~d}$ \\
AD or BD' & $1,4-1,6 \mathrm{~d}$ \\
D'F or BF & $1,3-1,9$ \\
FG & $2-3 \mathrm{~d}$ \\
GG & $50-70 \%$ \\
Sudut kantong Panjang dinding pintu masuk hingga ujung corong kedalam & $\left(16^{0}-21^{0}\right)$ \\
\hline
\end{tabular}

*d adalah kedalaman perairan tempat pemasangan posisi badan setnet. 


\section{model dan sasaran}

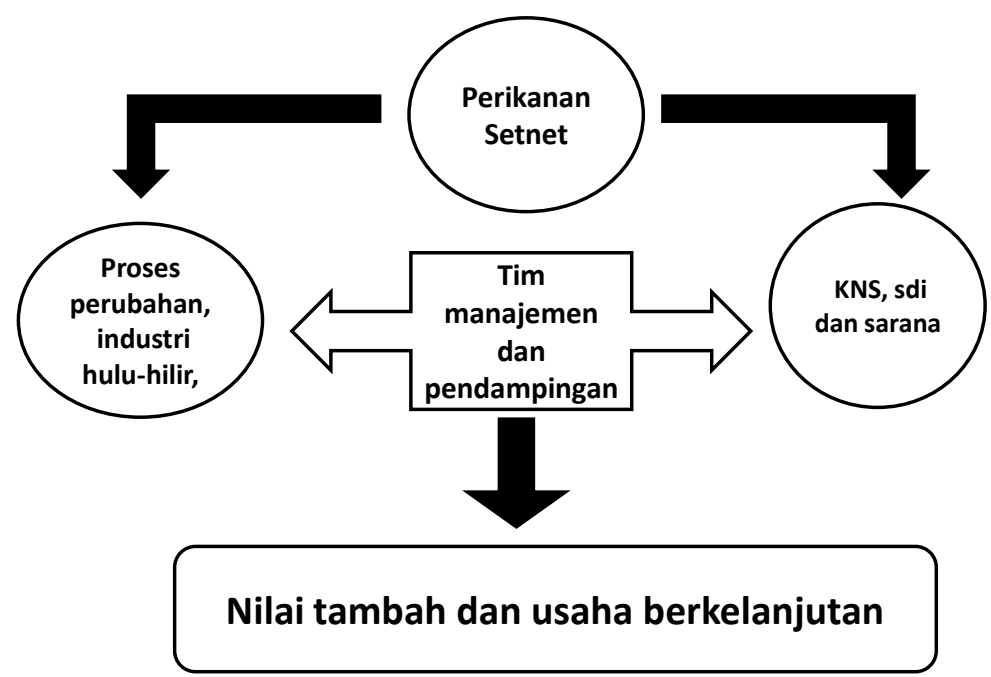

Gambar 2 Skema pengembangan setnet

Pada tahun 2009 merupakan awal pemasangan setnet di Kabupaten Jeneponto, Sulawesi Selatan yang operasionalnya dimulai tahun 2010. Pendampingan awal adalah perbaikan konstruksi hingga setnet sudah mulai dapat dioperasionalkan. Pada tahun 2011-2012 merupakan tahapan perubahan konstruksi setnet kantong dua diperbaiki dengan penyesuaian desain jaring dan penguatan kerangka setnet.

Tujuan kegiatan pendampingan pada pengembangan setnet, adalah memberikan pembinaan dan melakukan pengamatan hasil tangkapan dan perbaikan konstruksi setnet yang telah terpasang di Jeneponto dan menyediakan jaring cadangan sebagai pengganti bagian jaring yang dibersihkan untuk mengantisipasi masa tunggu penjemuran jaring.

Maksud pendampingan adalah untuk mengoptimalkan kinerja setnet selama operasional dengan pengelolaan pengoperasian dan memberdayakan kemampuan kelompok nelayan setnet agar tetap merawat dan menjaga keberlanjutannya. Kegiatan pendampingan uji coba setnet di Jeneponto diharapkan menjaga keberlanjutan pengelolaan setnet di Jeneponto melalui kerjasama pembinaan bidang teknis dan manajemen dengan pihak Pemerintah Daerah Kabupaten Jeneponto dan Kelompok Nelayan yang lebih profesional dan memiliki semangat melaksanakan operasional setnet dalam hal: perawatan unit setnet, pengoperasian setnet, menangani hasil tangkapan setnet lebih bernilai, di-siplin kerja dan bertanggung jawab terhadap lingkungan perikanan.

Kegiatan pendampingan yang dilakukan BBPPI selama tahun 2012 meliputi beberapa tahapan yaitu tahapan penyiapan implementasi kegiatan pendampingan, pendampingan evalu- asi kinerja pengoperasian setnet, penyesuaian konstruksi dan penyiapan kebutuhan bahan cadangan setnet, dan pengamatan hasil pengoperasian setnet.

Keluaran pendampingan diharapkan dapat meningkatkan kinerja pengelolaan setnet dengan capaian hasil tangkapan optimal dengan frekuensi pengoperasian yang meningkat.

\section{HASIL DAN PEMBAHASAN \\ Konsultansi Konstruksi Setnet \\ Penyesuaian dimensi dan bagian-bagian ruang setnet}

Dimensi utama ruang setnet terkait ukuran unit jaring yang diterapkan tetap berdasarkan hitungan berpedoman MATSUNAGA. Dari hasil pemeriksaan konstruksi setnet yang telah terpasang diukur dimensi jaring dan bagianbagian ruang setnet telah nyata sesuai dengan pedoman MATSUNAGA, kecuali beberapa bagian yang dilebihkan (EE') untuk penyesuaian panjang perahu bantu dan untuk optimalisasi volume ruang bagian kantong (chamber). Sudut kemiringan bagian jaring yang menaik (slender net) mendekati maksimal (20\%) untuk memaksimalkan sasaran ikan meso pelagis (Tabel 2). Pada modifikasi konstruksi jaring badan setnet diperdalam sehingga sudut kemiringan kepintu kantong kian landai.

Posisi badan setnet bertepatan pada kedalaman perairan 20 meter, sehingga penggunaan tali ponton dan tali cabang penyokong konstruksi rangka badan setnet menyesuaikan kedalaman perairan dengan penggunaan kedalaman tali berkisar 30 meter atau dilebihkan secukupnya. 
Sistem tali-temali rangka setnet terdiri dari tali poton dan tali cabang. Posisi badan setnet dipilih pada posisi yang relatif datar sehingga panjang tali ponton relatif sama. Peruntukan tali ponton pada bagian badan setnet terdiri dari 5 unit tali ponton utama badan setnet dan 8 unit tali pembantu badan setnet. Satu tali ponton utama dipasang pada bagian ujung dari penaju (leadernet). Pada bagian penaju atau leadernet dilengkapi tali cabang yang panjangnya disesuaikan kedalaman tempat pemasangan masing-masing tali cabang. Dengan penambahan satu kantong, maka kebutuhan jumlah sand bag bertambah dari 2500 menjadi 3000 kantong yang masing-masing beratnya $60 \mathrm{~kg}$ (Tabel 3).

Gambar 3 merupakan ilustrasi susunan tali kerangka dan posisi kantong yang siap dipasang pada sebelah kiri badan setnet sedangkan bila dikehendaki tambahan kantong pada badan bagian kanan maka dapat dimodifikasi dengan tambahan kerangka untuk pemasangan kantong sebelah kanan.

\section{Penguatan konstruksi kerangka setnet}

Setnet selamanya diletakkan di perairan sehingga diperlukan konstruksi kerangka setnet yang kokoh ketika dipasang unit jaring setnet dan mampu menahan derasnya gerakan massa air laut (arus dan gelombang). Kerangka setnet 2 kantong yang dipasang di perairan Libukan, Jeneponto mempunyai nilai kekokohan berdasarkan perbandingan daya tenggelam dan daya apung kerangka yaitu 79500,00 kgf : 17435,81 4,56:1. Bentang-rentang vertikal kerangka diangkat oleh daya apung sebesar 17,44 ton daya, sementara kemampuan menahan sebesar 4.56 kali lipat daya apung tersebut terhadap daya beban sebesar 79,5 ton daya (lihat rincian Tabel 4).

Peran pelampung utama sangat penting untuk pengencangan kerangka badan setnet secara memanjang, dan perentangan jaring secara vertikal, demikian juga untuk pengen- cangan leader-net. Beban tali pendukung pada setiap bagian diperkuat dengan beban yang lebih sehingga jumlah pemasangan tali pendukung relatif dapat dikurangi.

Unit jaring setnet terdiri: 1) daya beban total jaring kantong utama (la) terbuat dari tetoron rajutan Raschel yang bersifat tenggelam $=112,95 \mathrm{kgf}$. Bagian ini diharapkan stabil dalam air untuk ruang gerak ikan yang tertangkap agar tetap hidup dan bermain didalam ruang kantong tersebut. 2) Jaring pada bagian badan setnet lainnya berdaya apung sebesar 61,4 kgf dimaksudkan agar perilaku jaring lebih fleksibel. Keseluruhan daya beban jaring kantong dan bagian jaring pada badan setnet ditahan oleh 16,25 ton daya. 3) Jaring leader sepanjang 300 meter berdaya apung 94,8 kgf ditahan oleh 947,725 kgf. Secara keseluruhan unit jaring setnet digantung pada kerangka setnet yang berdaya apung 17,44 ton. Disamping itu pada unit jaring dilengkapi 4) pelampung jaring = 135,072 kgf; dan 5) pemberat jaring $=403,51 \mathrm{kgf}$.

\section{Pendampingan Selama Operasional}

\section{Kegiatan operasional setnet}

Hasil tangkapan selama operasionalisasi setnet di Jeneponto pada tahun 2010, ketika konstruksi setnet berkantong satu dari 83 kali pengoperasian mencapai 10,3 ton senilai 29,7 juta dengan jumlah berat rata-rata ikan ekonomis penting $124 \mathrm{~kg}$ per hari/haul. Pada tahun 2011, ketika konstruksi setnet dimodifikasi menjadi berkantong dua, selama 91 hari operasi hasil tangkapan secara keseluruhan sebesar 25,4 ton atau rata-rata $279,2 \mathrm{~kg}$ per hari/haul. Total nilai yang diperoleh selama 91 hari operasi sebesar Rp 135.365.500,-. Selama periode Januari hingga November 2012 dengan 135 kali hari operasi setnet telah diperoleh hasil tangkapan sebesar 25 ton ikan bernilai jual 158,9 juta rupiah. Bila dirata-ratakan, diperkirakan setiap harinya dengan sekali pengangkatan memperoleh hasil tangkapan $185 \mathrm{~kg}$.

Tabel 2. Frekuensi lolosnya kepiting bakau pada bentuk escape gap berbeda

\begin{tabular}{llc}
\hline \multicolumn{1}{c}{ Bagian Jaring } & Ketentuan Teknis & $\begin{array}{c}\text { Realisasi } \\
\text { Pemeriksaan }\end{array}$ \\
\hline $\begin{array}{l}\text { Lebar bukaan pintu masuk pertama masuk play ground/ } \\
\text { entrance ( } A B \text { ) }\end{array}$ & $=100-150 \%$ & $19,5 \mathrm{~m}(130 \%)$ \\
AC or $B C^{\prime}($ Wing) & $30-35 \%$ & $29 \%$ \\
$D D^{\prime}=A B$ & $1,5-3 \mathrm{~d}$ & $19,5 \mathrm{~m}(1,3 \mathrm{~d})$ \\
AE or DE & $80-100 \%$ & $12 \mathrm{~m}(80 \%)$ \\
E E' & $80-100 \% \mathrm{~d}$ & $130 \%$ \\
AD or BD' & $1,4-1,6 \mathrm{~d}$ & $1,3 \mathrm{~d}$ \\
D'F or BF & $1,3-1,9$ & $25,6 \mathrm{~m}(1,7 \mathrm{~d})$ \\
FG & $2-3 \mathrm{~d}$ & $44 \mathrm{~m}(2,9 \mathrm{~d})$ \\
GG & $50-70 \%$ & $8,84 \mathrm{~m}(0,59)$ \\
Sudut kantong Panjang dinding pintu masuk hingga ujung & $\left(16^{0}-21^{0}\right)$ & $20^{\circ}$ \\
corong kedalam & & \\
\hline
\end{tabular}


Tabel 3 Frekuensi lolosnya kepiting bakau pada posisi escape gap berbeda

\begin{tabular}{|c|c|c|c|c|}
\hline No & Nama komponen & Ukuran (Kg) & Jumlah & Daya beban (gf) \\
\hline 1 & Pemberat utama(sand bag ) & 60 & $2 \times 40(2)$ & 4.800 \\
\hline 2 & Pemberat utama(sand bag ) & 60 & $2 \times 12(2)$ & 1.440 \\
\hline 3 & Pemberat utama(sand bag ) & 60 & $2 \times 40(2)$ & 4.800 \\
\hline 4 & Pemberat utama(sand bag ) & 60 & $2 \times 12(2)$ & 1.440 \\
\hline 5 & Pemberat utama kanan & 60 & $2 \times 40(2)$ & 4.800 \\
\hline 6 & Pemberat utama kiri & 60 & $2 \times 40(2)$ & 4.800 \\
\hline 7 & Pemberat sand bag knn & 60 & $25(1)$ & 1.500 \\
\hline 8 & Pemberat sand bag kr & 60 & $25(1)$ & 1.500 \\
\hline 9 & Pemberat kerangka & 60 & $2 \times 40(2)$ & 4.800 \\
\hline 10 & Pemberat kerangka & 60 & $2 \times 40(2)$ & 4.800 \\
\hline 11 & Pemberat kerangka & 60 & $2 \times 40(2)$ & 4.800 \\
\hline 12 & Pemberat kerangka & 60 & $2 \times 40(2)$ & 4.800 \\
\hline 13 & Pemberat kerangka & 60 & $2 \times 40(2)$ & 4.800 \\
\hline 14 & Pemberat kerangka & 60 & $2 \times 40(2)$ & 4.800 \\
\hline 15 & Pemberat kerangka & 60 & $2 \times 40(2)$ & 4.800 \\
\hline 16 & Pemberat kerangka & 60 & $2 \times 40(2)$ & 4.800 \\
\hline 17 & Pemberat kerangka & 60 & $2 \times 40(2)$ & 4.800 \\
\hline 18 & Pemberat kerangka & 60 & $2 \times 40(2)$ & 4.800 \\
\hline 19 & Pemberat kerangka & 60 & $2 \times 40(2)$ & 4.800 \\
\hline 20 & Pemberat kerangka & 60 & $2 \times 40(2)$ & 4.800 \\
\hline 22 & Pemberat kerangka & 60 & $2 \times 40(2)$ & 4.800 \\
\hline 23 & Pemberat kerangka & 60 & $2 \times 40(2)$ & 4.800 \\
\hline 24 & Pemberat kerangka & 60 & $2 \times 40(2)$ & 4.800 \\
\hline 25 & Pemberat kerangka & 60 & $2 \times 40(2)$ & 4.800 \\
\hline 26 & Pemberat kerangka & 60 & $2 \times 40(2)$ & 4.800 \\
\hline 27 & Pemberat kerangka & 60 & $2 \times 40(2)$ & 4.800 \\
\hline 28 & Pemberat kerangka & 60 & $2 \times 40(2)$ & 4.800 \\
\hline 29 & Pemberat kerangka & 60 & $2 \times 40(2)$ & 4.800 \\
\hline 30 & Pemberat kerangka & 60 & $2 \times 40(2)$ & 4.800 \\
\hline 31 & Pemberat kerangka & 60 & $2 \times 40(2)$ & 4.800 \\
\hline 32 & Pemberat kerangka & 60 & $2 \times 40(2)$ & 4.800 \\
\hline 34 & Pemberat kerangka & 60 & $2 \times 40(2)$ & 4.800 \\
\hline 35 & Pemberat kerangka & 60 & $2 \times 40(2)$ & 4.800 \\
\hline \multirow[t]{2}{*}{36} & Pemberat kerangka & 60 & $2 \times 40(2)$ & 4.800 \\
\hline & & & 80 & 149.880 \\
\hline
\end{tabular}

Tabel 4 Rincian bahan kerangka setnet dengan menghitung daya apung dan tenggelam

\begin{tabular}{|c|c|c|c|c|c|}
\hline No & Peruntukkan & Spesifikasi & Volume & Berat & $\begin{array}{c}\text { Daya: apung }(-) \\
\text { tenggelam }(+)\end{array}$ \\
\hline 1 & Tali Kerangka & Pp-danline-rope $\varnothing 32 \mathrm{~mm}$ & $1025 \mathrm{~m}$ & $471,5 \mathrm{~kg}$ & $66,01 \mathrm{kgf}(-)$ \\
\hline 2 & Tali sokong kerangka & PE rope $\varnothing 26 \mathrm{~mm}$ & $2425 \mathrm{~m}$ & $763,9 \mathrm{~kg}$ & $61,11 \mathrm{kgf}(-)$ \\
\hline 3 & Tali Gantung jaring L & PPdanline rope $\varnothing 30 \mathrm{~mm}$ & $500 \mathrm{~m}$ & $202,5 \mathrm{~kg}$ & $28,35 \mathrm{kgf}(-)$ \\
\hline 4 & Tali Gantung jaring B & $\mathrm{PE} \varnothing 22 \mathrm{~mm}$ & $715 \mathrm{~m}$ & $160,9 \mathrm{~kg}$ & $12,87 \mathrm{kgf}(-)$ \\
\hline 5 & Tali sokong kerangka & PP rope, $\varnothing 14 \mathrm{~mm}$ & $1890 \mathrm{~m}$ & $170,1 \mathrm{~kg}$ & $23,81 \mathrm{kgf}(-)$ \\
\hline 6 & Tali PE rope & PE rope $\varnothing 14 \mathrm{~mm}$ & $770 \mathrm{~m}$ & $70,1 \mathrm{~kg}$ & $5,61 \mathrm{kgf}(-)$ \\
\hline 7 & Tali ikat sanbag & PE rope $\varnothing 8 \mathrm{~mm}$ & $15000 \mathrm{~m}$ & $450,0 \mathrm{~kg}$ & $36,0 \mathrm{kgf}(-)$ \\
\hline 9 & Sand bag-jangkar & Sak plastik kerikil dan pasir & 3000 sak & 150 ton & $79.500,00 \mathrm{kgf}(+)$ \\
\hline 10 & Pelampung kerangka 1 & Plastik $\varnothing 30 \mathrm{~cm}(-14,46 \mathrm{kgf})$ & $1124 \mathrm{biji}$ & & $16.254,32 \mathrm{kgf}(-)$ \\
\hline 11 & Pelampung kerangka 2 & Plastik $\varnothing 24$ cm (-7,404 kgf) & 128 biji & & $947,725 \mathrm{kgf}(-)$ \\
\hline 12 & Jaring leader & 400D/90 PE, MS 242,2mm & $\begin{array}{l}3250 \mathrm{MD} \times 1 \\
30 \mathrm{ML}\end{array}$ & 1185 kg & $94,8 \mathrm{kgf}(-)$ \\
\hline
\end{tabular}

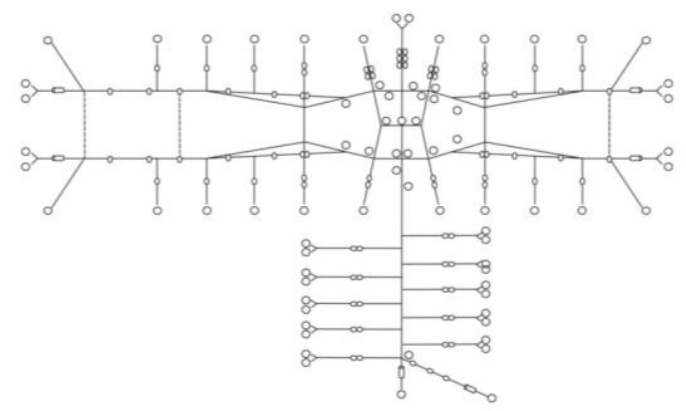

Gambar 3 Susunan tali kerangka dan posisi kantong 


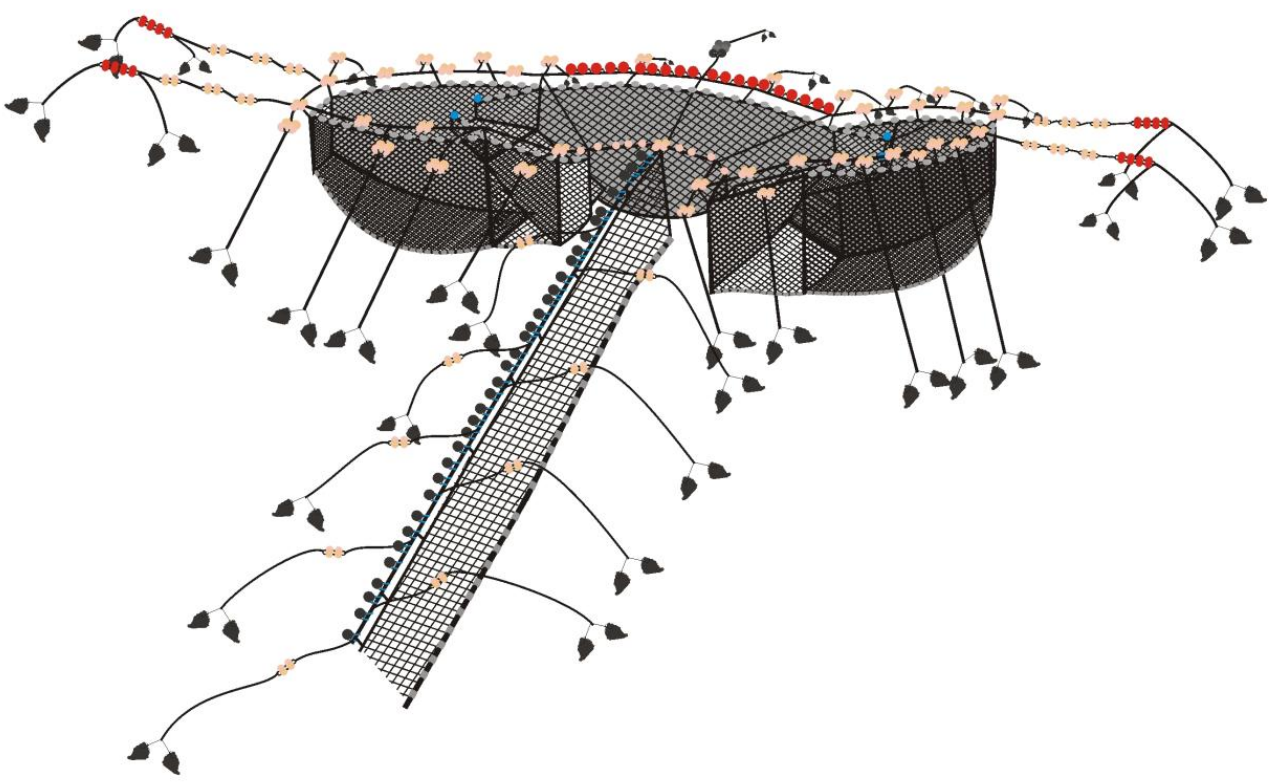

Gambar 4 llustrasi Perspektif setnet kantong 2

Pengoperasian setnet dari tahun ke tahun cenderung meningkat dengan jumlah hari operasi yang bertambah, namun baik dari total hasil tangkapanan maupun hasil tangkapanan rata-rata per hari dengan sekali pengangkatan mengalami fluktuasi. Hasil tangkapan tidak selalu berkorelasi dengan nilai jual ikan yang berhasil ditangkap. Demikian pula hasil tangkapan harian dalam periode tertentu masih fluktuatif sehingga masih kasar untuk melihat angka rata-rata.

Dari nilai total hasil tangkapan cenderung meningkat artinya dengan biaya operasional yang kecil maka jumlah berat hasil tangkapan seluruhnya tetap memberikan keuntungan yang lebih baik. Berikut adalah jumlah hari operasi, hasil tangkapan dan nilai jual selama operasional setnet kantong dua tahun 2011 dan tahun 2012 (Tabel 5 dan Tabel 6).

\section{Pengaruh kondisi perairan terhadap operasional setnet}

Keaktifan operasional setnet dipengaruhi oleh beberapa faktor utamanya baik yang bersifat alamiah (cuaca, kondisi laut) maupun faktor teknis. Faktor cuaca dalam periode tertentu dapat diduga, namun sering terjadi perubahan yang sulit diantisipasi sehingga setnet sering mengalami kerusakan atau jaring menjadi kotor sebelum diangkat ke darat. Kerusakan parah terjadi bila sand bag bergeser sehingga bentuk kerangka berubah tidak teratur, tekanan akibat desakan arus tidak sama dan sebagian mendapat beban berlebih dan bila terjadi putus pada sebagian tali kerangka dan/atau tali penyangga maka jaring harus segera diangkat.
Arus yang berlebih sering mengakibatkan jaring kantong atau badan bagian pintu setnet terangkat, sehingga ikan tidak bisa masuk ke badan setnet atau keluar lagi dari badan setnet karena pintu masuk kantong tertutup dan kantong ter-angkat. Walaupun jaring setnet terpasang tapi tidak ada ikan masuk. Misal pada bulan Januari 2012 jaring setnet terpasang selama 11 hari tetapi efektifitas pengoperasian hanya 5 hari. Hal serupa terjadi pada bulan/periode lain, seperti: pada periode 17 Maret-2 April jaring terpasang 18 hari yang efektif beroperasi 15 hari, pada periode 19 April -27 Mei jaring terpasang 38 hari yang efektif 34 hari, pada periode 10 juli-11 Agustus jaring terpasang 31 hari yang efektif beroperasi 27 hari, pada periode 25 Oktober-18 November jaring terpasang 25 hari yang efektif beroperasi 20 hari. Oleh karena itu masalah perubahan cuaca menjadi perhatian segenap kelompok nelayan meskipun sulit, perlu perawatan yang teliti dan waktu yang lama. Meskipun demikian secara teknis harus diantitisipasi dengan adanya pe-ngadaan cadangan komponen setnet baik komponen yang ada di badan setnet seperti: bagian kantong, bagian serambi dan sloppe; maupun komponen jaring pada penaju/ leader.

Perawatan setnet meliputi: kegiatan pencucian jaring dari teritip, bagian-bagian tali kerangka dan pelampung yang tertempel teritip, tali penyangga tali kerangka, dan kondisi sand bag. Perawatan pencucian jaring bagian kantong sering dilakukan sehingga setnet terpaksa beroperasi dengan satu kantong dan hal ini dapat mempengaruhi efektifitas hasil tangkapan. Kehadiran cadangan satu unit kantong setnet 
diperlukan untuk menjaga konsistensi dan efektifitas hasil tangkapan.

Pencucian juga harus dilakukan pada komponen jaring bagian serambi dan slope. Meskipun demikian kehadiran cadangan bagian serambi dan slope ini juga sangat diperlukan. Sesuai pengadaan tahun 2012 komponen serambi dan slope baru diadakan yang penyelesaiannya bulan Desember 2012. Oleh karena itu para ABK setnet selama periode OktoberNovember mengerjakan pembuatan komponen jaring bagian serambi dan slope.

Gangguan dengan perawatan paling beresiko adalah bila terjadi pergeseran sand bag. Jika tidak segera ditangani maka konstruksi setnet dapat berakibat rusak parah. Kejadian ini dialami pada periode 1-24 Oktober dengan mereposisi titik-titik sand bag dan mengganti sekaligus memperkuat kedudukan sand bag. Pembenahan sand bag dirasakan rumit dan biayanya mahal. Pembetulan bagian tali kerangka juga dilakukan pada periode JanuariMaret 2012.

Jadi pentingnya pendampingan ini adalah pembinaan yang terus-menerus dalam perawatan dan menjaga keutuhan setnet di lokasi. Dalam hal ini yang menjadi target adalah terjadinya keberlanjutan pengoperasian setnet, antara lain dengan mengupayakan peningkatan jumlah hari operasi per tahun. Pada tahun 2010 jumlah hari operasi sebanyak 83 kali hari operasi, tahun 2011 meningkat menjadi 91-97 kali hari operasi dan tahun 2012 sampai dengan bulan November telah dilakukan sebanyak 135 hari operasi. Operasional setnet tahun 2012 seperti tertera pada Tabel 7.

\section{Kinerja kedua kantong terhadap peluang ikan masuk}

Masing-masing di antara dua kantong setnet memiliki posisi dan konstruksi yang berbeda. Kantong lama berada pada posisi yang menghadap kearah selat atau lebih dekat dengan pulau, kantong baru berada di sebaliknya yaitu menghadap ke arah Teluk. Konstruksi kantong lama menggantung dengan sudut kemiringan jaring pintu kearah masuk kantong menukik atau lebih tajam, sedangkan kantong baru lebih dalam menyesuaikan kedalaman 20 meter dengan sudut kemiringan pintu masuk kearah kantong lebih landai.

Hasil tangkapan setnet sangat ditentukan oleh konsistensi keberadaan jaring setnet dengan konstruksi jaring dan kerangka setnet yang mantap dan siap menerima tamu ruaya ikan yang akan melewatinya. Semakin dapat diketahuinya rutinitas ruaya sepanjang tahun akan semakin jelas modus kehadiran kelim- pahan ruaya ikan hari demi hari hingga musim demi musim dengan meningkatkan frekuensi jumlah hari operasi.

Dalam perikanan multi species kehadirannya didalam kantong memiliki perilaku yang beragam sehingga peluang ikan masuk kedalam kantong setnet perlu diamati bersamaan musim ikan. Fluktuasi jumlah ikan yang masuk dipengaruhi oleh musim dan sifat gerombolan ikan sesuai dengan kelompok jenis ikan.

Berdasarkan pengamatan jumlah ikan yang masuk kedalam masing-masing kantong setnet terlihat kecenderungan frekuensi dan jumlah ikan yang masuk kedalam masingmasing kantong. Secara umum kantong baru berpeluang lebih banyak ikan yang masuk kecuali pada musim tertetntu dan beberapa kelompok ikan tertentu.Dari hasil pengamatan pada bulan Oktober-November 2012 frekuensi ikan yang masuk kedalam kantong lama lebih banyak, dan seperti ikan kuwe (giant trevally) yang secara aksidental sepenuhnya masuk ke dalam kantong lama (Tabel 8).

Menurut tabel 8, pada bulan Mei 2012 ketidakhadiran kantong secara bersamaan berpengaruh terhadap frekuensi ikan yang masuk ke dalam kantong sehingga dengan sejum lah 26 hari operasi tinggal 20 kali ikan masuk kedalam kantong setnet. Peran keberadaan kantong cadangan cukup menentukan efektifitas hari operasi atau operasionalisasi setnet.

\section{Pengamatan jenis ikan hasil tangkapanan setnet dan pendayagunaannya}

Dari hasil pengamatan tanggal 30 November 2012 disajikan pada Tabel 9 dan Tabel 10. Pada saat pengamatan diperoleh total hasil tangkapan $286 \mathrm{~kg}$ dengan komposisi terbesar beberapa species seperti ikan petek (bete-bete): $80 \mathrm{~kg}(27,9 \%)$, ikan cendro: $75 \mathrm{~kg}$ (26,2\%), Tembang: $50 \mathrm{~kg}(17,5 \%)$, ikan selar bentrong: $20 \mathrm{~kg}(7 \%)$, ikan alu-alu: $12 \mathrm{~kg}$ $(4,2 \%)$, ikan kuwe: $10 \mathrm{~kg}(3,5 \%)$, ikan selar: 8 kg (2,8\%), ikan julung-julung: $8 \mathrm{~kg}(2,8 \%)$, parang-parang: $5 \mathrm{~kg}(1,7 \%)$, ikan layur: $4 \mathrm{~kg}$ $(1,4 \%)$, barakuda: $2,5 \mathrm{~kg}(0,9 \%)$, dan ikan tenggiri: $2 \mathrm{~kg}(0,7 \%)$. Jenis komoditas ekonomis penting lainnya seperti cumi-cumi, sotong, ikan kuwe, ikan baronang dan ikan kembung. Hasil tangkapan dengan nilai tertinggi adalah ikan layur berukuran panjang total: 73-91 cm. Ikan berukuran besar lainnya: ikan cendro: 45-75 $\mathrm{cm}$, tenggiri: $40-65 \mathrm{~cm}$.

Hasil pengamatan tanggal 1 Desember 2012 lebih banyak diperoleh ikan ekonomis penting dengan total hasil tangkapan $317,4 \mathrm{~kg}$. Komposisi terbesar dari beberapa ikan ekonomis penting terdiri species seperti ikan 
alu-alu: $80 \mathrm{~kg}(25,2 \%)$, ikan tenggiri: $60 \mathrm{~kg}$ $(18,9 \%)$, cendro: $40 \mathrm{~kg}(12,6 \%)$, ikan layur: 30 $\mathrm{kg}(9,5 \%)$ ikan tenggiri papan: $15 \mathrm{~kg}(4,7 \%)$, ikan petek: $15 \mathrm{~kg}$ (4,7\%), barakuda 1: $15 \mathrm{~kg}$ $(4,7 \%)$, barakuda $2: 10 \mathrm{~kg}(3,2 \%)$, kembung lelaki : $10 \mathrm{~kg}(3,2 \%)$, Tetengke: $10 \mathrm{~kg}(3,2 \%)$, bawal hitam: $5 \mathrm{~kg}(1,6 \%)$, cumi: $3 \mathrm{~kg}(0,9 \%)$. Hasil tangkapan dengan nilai tertinggi adalah ikan layur berukuran panjang total: $54-90 \mathrm{~cm}$. Ikan berukuran besar: ikan tenggiri: $80-120 \mathrm{~cm}$, bawal hitam: $44-48 \mathrm{~cm}$, tenggiri papan: $25-35$ $\mathrm{cm}$, barakuda: $36-45 \mathrm{~cm}$, parang-parang: 60 $75 \mathrm{~cm}$.

Berdasarkan hasil identifikasi komposisi jenis tangkapan yang diperoleh terlihat bahwa jenis species yang diamati terbagi kedalam tiga kelompok besar. Yang pertama, kelompok ikan pelagis yang hidup cenderung di dekat permukaan perairan diantaranya: alu-alu, julung-julung, cendro, cakalang, tenggiri, tuna, kembung, selar, tembang, sardin, tetengkek, dan layur.

Kelompok ikan pelagis kecil yang hidup cenderung dekat dengan permukaan perairan memiliki bentuk tubuh relatif bulat memanjang, seperti yang ditemukan pada ikan alu-alu, julung-julung, dan cendro. Bentuk tubuh ini merupakan suatu bentuk adaptasi morfologi yang digunakan dalam mobilitas tingkah laku ikan dalam merespon kondisi lingkungan habitatnya yang ekstrim. Permukaan yang senantiasa Berkantong Dua bergejolak akibat arus yang kuat, gelombang yang besar, atau pun angin yang kencang menyebabkan ikanikan pada kelompok ini mengharuskan memiliki daya renang yang besar. Hal ini berdampak pada tangkapan Setnet Berkantong Dua, dimana pada saat kecepatan arus yang besar, ikan-ikan pada kelompok ini cenderung relatif lebih banyak tertangkap dibandingkan dengan kelompok lainnya.

Adapun jenis-jenis ikan pelagis kecil yang tertangkap setnet berkantong dua di Jeneponto didominasi oleh jenis layur (Trichiurus sp.), petek (Leiognathus spp.), dan cendro (Tylosurrus spp.).

Kedua, kelompok ikan pelagis yang cenderung berada di bagian pertengahan kolom perairan diantaranya: peperek, talang-talang, layur, kitan, kuwe, dan baronang.

Kelompok ikan pelagis yang hidup dibagian pertengahan perairan, cenderung memiliki bentuk tubuh yang relatif pipih (compressed fishes). Bentuk tubuh yang pipih juga merupakan adaptasi morfologi terhadap lingkungan habitatnya dimana tingkah laku ikan ini yang cenderung melawan ataupun mengikuti arus di tengah/kolom perairan. Ikan yang berbentuk pipih (compressed) cenderung memiliki kecepatan renang yang lebih lambat dibandingkan dengan ikan yang berbentuk torpedo memanjang (elongated) memberikan kemudahan dalam mempertahankan posisi dan kecepatan renangnya (swimming performance) di dalam kolom perairan. Ikan-ikan kelompok ini biasanya tertangkap pada setnet berkantong dua dengan membentuk gerombolan besar, seperti pada ikan kuwe.

Ketiga, kelompok ikan demersal diantaranya: biji nangka, kakap merah, bambangan, hiu, gabus, sembilan karang, kerong-kerong, cumi-cumi, dan lobster.

Kelompok ikan demersal memiliki bentuk tubuh yang sedikit pipih (slightly compressed fishes) dan pada bagian bawahnya relative datar. Beberapa jenis ikan dilengkapi dengan sungut, seperti ikan biji nangka. Bentuk tersebut juga merupakan bentuk adaptasi morfologi dimana lingkungan habitatnya berada. Berdasarkan kedalaman perairan, diketahui bahwa kecepatan arus berkurang seiring bertambahnya kedalaman, dan juga termasuk intensitas pencahayaan. Berdasarkan kondisi ini, sehingga disadari bahwa ikan-ikan kelompok ini relatif tingkah laku berrenangnya lebih lambat dan tidak bermigrasi jauh serta mengutamakan pada perkembangan indera penciumannya.

Disamping pendekatan analisis morfologi jenis hasil tangkapanan terhadap habitat ekosistemnya, pendekatan organ-organ sensor merupakan fundamental science yang mampu mengungkapkan secara physiologi, bagaimana jenis-jenis hasil tangkapanan dalam merespon alat tangkap setnet berkantong dua di dalam perairan. Beberapa penelitian dasar yang telah dilakukan dalam pengungkapan tersebut, diantaranya adalah penentuan tingkat ketajaman penglihatan ikan (visual acuity), jarak pandang maksimum (maximum sighting distance) terhadap alat tangkap setnet dan penentuan arah ketajaman penglihatan ikan (visual axis).

Berdasarkan fluktuasi hasil tangkapanan harian setnet berkantong dua selama pengamatan dilaksanakan. Berdasarkan data hasil tangkapanan yang diperoleh terlihat bahwa terdapat perbedaan berat hasil tangkapan pada setiap operasi penangkapan harian, yang diikuti oleh perbedaan nilai hasil tangkapanannya. Berat hasil tangkapanan cenderung berkorelasi positif terhadap nilai hasil tangkapanan, walaupun demikian juga terdapat kasus dimana berat tangkapan yang lebih rendah memberikan nilai tangkapan yang lebih besar.

Fluktuasi tangkapan harian dalam hal berat dan nilai tangkapannya, ternyata bervariasi pula terhadap komposisi jenis hasil tang- 
kapan hariannya dimana rata-rata jenis tangkapan harian bervariasi antara 8-15 species per hari dengan nilai ekonomis yang berbeda-beda. Perbedaan komposisi jenis hasil tangkapanan harian mengindikasikan bahwa pola kedatangan jenis-jenis ikan ke wilayah perairan pesisir bervariasi pula secara harian.
Pemanfaatan hasil tangkapan setnet selain untuk konsumsi pangan juga untuk pakan budi daya laut. Salah satunya untuk pakan pada budi daya lobster. Ikan yang digunakan adalah ikan rucah berukuran kecil dari beberapa species seperti: kuniran, petek, barakuda, cendro, dan lain-lain.

Tabel 5 Hasil operasi setnet Jeneponto Agustus - Desember 2011

\begin{tabular}{lrrrrr}
\hline \multicolumn{1}{c}{ Bulan } & $\begin{array}{c}\boldsymbol{\Sigma} \text { KHari } \\
\text { Operasi }\end{array}$ & $\begin{array}{c}\text { Jumlah hasil } \\
\text { tangkapan } \mathbf{( k g )}\end{array}$ & $\begin{array}{c}\text { Rata-rata } \\
\mathbf{( k g )}\end{array}$ & Nilai (Rp) & Rata-rata (Rp) \\
\hline Agustus & 5 & $1.404,2$ & 280,8 & 8.243 .000 & 1.648 .600 \\
September & 30 & $10.397,6$ & 346,6 & 45.667 .000 & 1.522 .233 \\
Oktober & 21 & $6.337,6$ & 301,8 & 31.610 .500 & 1.505 .262 \\
November & 14 & $2.351,0$ & 167,9 & 10.413 .000 & 743.786 \\
Desember & 21 & $4.915,6$ & 234,1 & 39.432 .000 & 1.877 .714 \\
\hline \multicolumn{1}{c}{ Jumlah } & $\mathbf{9 1}$ & $\mathbf{2 5 . 4 0 6 , 0}$ & $\mathbf{2 7 9 , 2}$ & $\mathbf{1 3 5 . 3 6 5 . 5 0 0}$ & $\mathbf{1 . 4 8 7 . 5 3 3}$ \\
\hline \multicolumn{1}{c}{ Rata-rata } & $\mathbf{2 7 9 , 2}$ & $\mathbf{1 . 4 8 7 . 5 3 3}$ & \\
\hline
\end{tabular}

Tabel 6 Hasil tangkapan dan nilai jual selama operasional setnet Januari-November 2012

\begin{tabular}{lccrrr}
\hline \multicolumn{1}{c}{ Bulan } & Hari operasi & Hasil tangkapan $\mathbf{( k g )}$ & Nilai Jual (Rp) & kg/trip & \multicolumn{1}{c}{ Rp/Trip } \\
\hline Jan & 5 & 807,6 & 9.375 .900 & 161,52 & 1.875 .180 \\
Febr & 0 & 0 & 0 & 0 & 0 \\
Maret & 25 & 4.418 & 29.041 .000 & 176,72 & 1.161 .640 \\
April & 8 & 1.804 & 4.356 .289 & 225,50 & $544.536,1$ \\
Mei & 26 & 3.441 & 15.630 .000 & 132,35 & $601.153,8$ \\
Juni & 0 & 0 & 0 & 0 & 0 \\
Juli & 17 & 4.596 & 40.330 .500 & 270,35 & 2.372 .382 \\
Agustus & 10 & 1.236 & 10.431 .100 & 123,60 & 1.043 .110 \\
September & 24 & 6.004 & 32.594 .100 & 250,17 & 1.358 .088 \\
Oktober & 6 & 1.112 & 9.907 .100 & 185,33 & 1.651 .183 \\
November & 14 & 1.589 & 7.237 .000 & 113,50 & $516.928,6$ \\
\hline Total & $\mathbf{1 3 5}$ & $\mathbf{2 5 . 0 0 7 , 6}$ & $\mathbf{1 5 8 . 9 0 2 . 9 8 9}$ & $\mathbf{1 8 5 , 2 4}$ & $\mathbf{1 . 1 7 7 . 0 5 9}$ \\
\hline
\end{tabular}

Tabel 7 Operasional setnet di Pulau Libukang, Jeneponto selama tahun 2012

\begin{tabular}{|c|c|c|c|}
\hline No & Periode & Uraian Kegiatan & Keterangan \\
\hline 1 & 1-11 Jan & $\begin{array}{l}\text { Setnet terpasang di laut : arus kencang berombak dengan jumlah hari } \\
\text { efektif } 5 \text { kali hari operasi }\end{array}$ & $5 \mathrm{HO}$ \\
\hline 2 & 12 Jan - 3 Maret & $\begin{array}{l}\text { Seluruh jaring dinaikkan di darat, perawatan jaring, perbaikan kasko fiber } \\
\text { dan mesin perahu setnet }\end{array}$ & - \\
\hline 3 & 4-14 Mar & Setnet beroperasi & $10 \mathrm{HO}$ \\
\hline 4 & 14-16 Mar & Dua kantong setnet ditiris dan dibersihkan & - \\
\hline 5 & 17 Mar - 2 April & Setnet beroperasi selama 15 kali hari operasi efektif & $15 \mathrm{HO}$ \\
\hline 6 & $3-18$ April & Seluruh setnet dinaikkan di darat untuk perawatan & \\
\hline 7 & 19 April -27 Mei & Setnet terpasang selama 38 hari dengan 34 kali hari operasi efektif & $34 \mathrm{HO}$ \\
\hline 8 & $28 \mathrm{Mei}-9$ Juli & Seluruh jaring setnet dinaikkan dan dibersihkan & \\
\hline 9 & 10 Juli - 11 Agust. & Setnet terpasang selama 31 hari dengan 27 kali hari operasi efektif & $27 \mathrm{HO}$ \\
\hline 10 & 12 Agust.- 5 Sept. & Seluruh Jaring setnet dinaikkan untuk perawatan & \\
\hline 11 & $6-30$ Sep & Setnet beroperasi dengan 24 hari efektif & $24 \mathrm{HO}$ \\
\hline 12 & $1-24$ Okt. & Seluruh jaring dibersihkan dan perbaikan kerangka penaju & \\
\hline 13 & 25 Okt. - 18 Nov. & Setnet beroperasi dengan 20 kali hari operasi efektif. & $20 \mathrm{HO}$ \\
\hline \multirow[t]{2}{*}{14} & $19-27 \mathrm{Nov}$ & Seluruh jaring dinaikkan untuk perawatan & \\
\hline & $28-29 \mathrm{Nov}$ & Penurunan dan pemasangan jaring setnet & \\
\hline 15 & 30 Nov -6 Des. & Pengoperasian setnet menggunakan $200 \mathrm{~m}$ panjang leader & $6 \mathrm{HO}$ \\
\hline
\end{tabular}


Tabel 8 Peluang ikan masuk kantong baru dan kantong lama setnet di Jeneponto 2012

\begin{tabular}{|c|c|c|c|c|c|c|}
\hline \multirow[b]{2}{*}{ Bulan } & \multirow{2}{*}{$\begin{array}{c}\Sigma \text { hari } \\
\text { operasi }\end{array}$} & \multicolumn{2}{|c|}{ Kantong Baru } & \multicolumn{2}{|c|}{ Kantong lama } & \multirow[b]{2}{*}{ Keterangan } \\
\hline & & Hasil (kg) & $\begin{array}{c}\text { Frek > } \\
\text { banyak }\end{array}$ & $\begin{array}{c}\text { Hasil } \\
\text { (kg) }\end{array}$ & $\begin{array}{c}\text { Frek > } \\
\text { banyak }\end{array}$ & \\
\hline Maret & 25 & 2.587 & 16 & 1.832 & 7 & Seri 2 \\
\hline Mei & 26 & 1.863 & 14 & 1.578 & 6 & $\mathrm{~KB}$ dan $\mathrm{KL}$ absen $6 \mathrm{x}$ \\
\hline Juli & 18 & 1.716 & 16 & 2.880 & 2 & Ikan kuwe 2053kg \\
\hline Agustus & 10 & 911 & 9 & 326 & 1 & \\
\hline September & 24 & 3.953 & 21 & 2.051 & 3 & \\
\hline Oktober & 6 & 322 & 0 & 790 & 6 & \\
\hline November & 14 & 626 & 4 & 963 & 10 & \\
\hline Total & 123 & 11.978 & 80 & 10.420 & 35 & \\
\hline
\end{tabular}

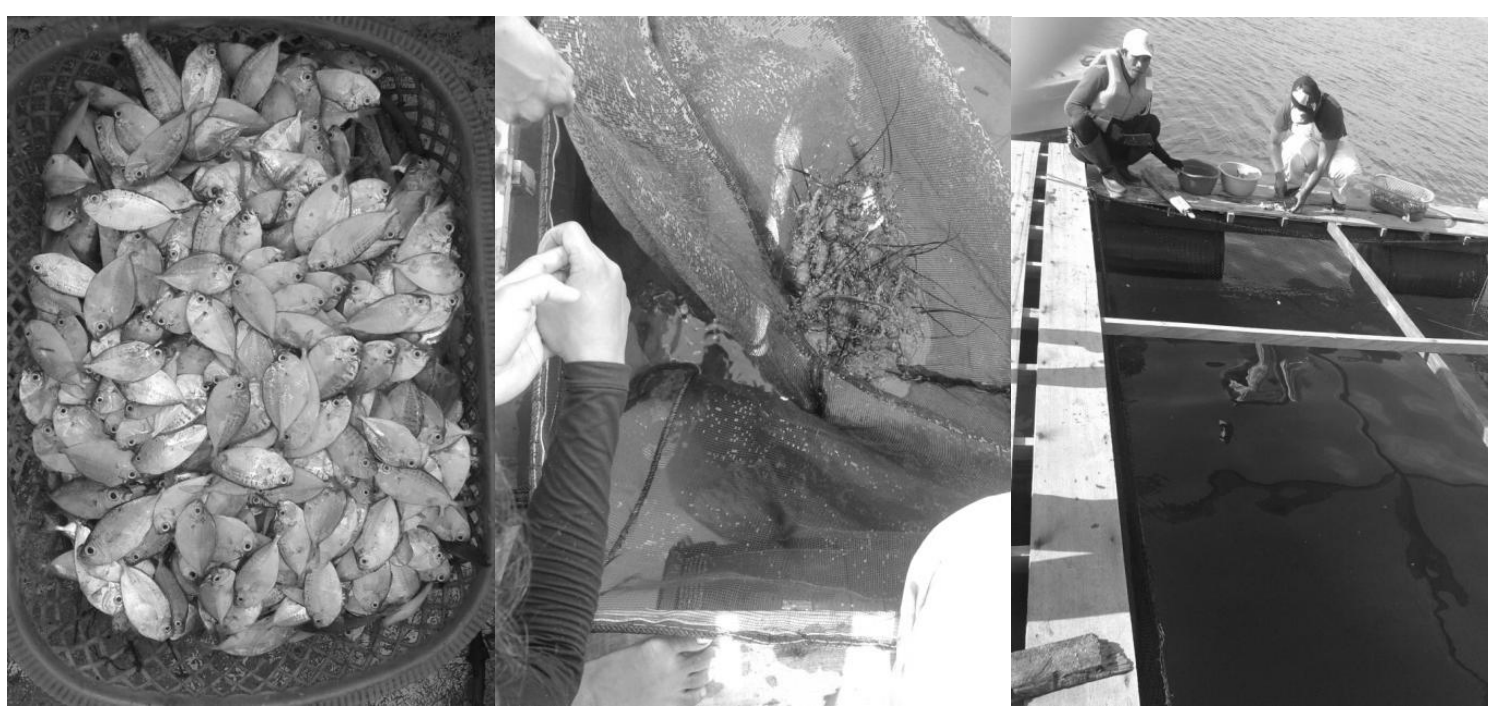

Gambar 5 Ikan pakan dan pemberian pakan di karamba lobster hasil tangkapan setnet

Tabel 9 Komposisi dan modus panjang ikan hasil tangkapan setnet tanggal 30 Nopember 2012

\begin{tabular}{|c|c|c|c|c|c|c|}
\hline Nama IImiah & Nama FAO & $\begin{array}{c}\text { Nama } \\
\text { Indonesia }\end{array}$ & Nama Lokal & $\begin{array}{c}\text { Berat } \\
(\mathrm{Kg})\end{array}$ & $\%$ & $\begin{array}{c}\text { Panj.Total } \\
\text { (cm) }\end{array}$ \\
\hline Sardinella fimbriata & Fringescale Sardine & Tembang & Tembang & 50 & 17,5 & $15-21$ \\
\hline Sphyraena baracuda & Great Barracuda & Barakuda & Menggila & 2,5 & 0,9 & $20-42$ \\
\hline Sphyraena jello & Banded Barracuda & Alu-alu & Loli-loli & 12 & 4,2 & $15-40$ \\
\hline Chorinemus tol & Deep Leathern Skin & Talang-talang & Pace-pace & 2 & 0,7 & $20-42$ \\
\hline Carangoides malabaricus & Trevally & Kuwe & Cirakmata & 10 & 3,5 & $18-25$ \\
\hline Atule mate & & Selar & & 8 & 2,8 & $21-28$ \\
\hline Leiognathus equulus & Yellowspot Ponyfish & Petek & Bete-bete & 80 & 27,9 & $12-20$ \\
\hline Tylossurus crocodyllus & Gar Fish & Cendro & Cendro labu & 75 & 26,2 & $45-75$ \\
\hline Trichiurus lepturus & Hair Tail & Layur & Layur & 4 & 1,4 & $73-91$ \\
\hline Scomberomorus commersoni & Barred Spanish & Tenggiri & Tinombo & 2 & 0,7 & $40-65$ \\
\hline Species unknown & & & & 3 & 1,0 & 35 \\
\hline Hemirhamphus sp. & Barred Garfish & Julung-julung & Jerulak & 8 & 2,8 & $20-35$ \\
\hline Selar crumenophthalmus & Bigeye Scad & Selar Bentong & & 20 & 7,0 & $14-20$ \\
\hline Chirocentrus dorab & Wolf Herring & Parang-parang & Bale-bale & 5 & 1,7 & $30-45$ \\
\hline Upeneus sulphureus & Yellow Goatfish & Kuniran & Ciko-ciko & 0,8 & 0,3 & $14-20$ \\
\hline Carangoides ciliaris & & Kuwe & Rambo-rambo & 0,5 & 0,2 & $15-22$ \\
\hline Rastrelliger kanagurta & Stripped Mackerel & Kembung lelaki & Kombong & 0,5 & 0,2 & $14-22$ \\
\hline Dussumieria acuta & Round Herring & Japuh & Tembang jawa & 0,4 & 0,1 & $12-18$ \\
\hline Thryssa mystax & & Daun Bambu & Cambang-cambang & 0,5 & 0,2 & $8-14$ \\
\hline Siganus sp. & Streaked Strikefoot & Baronang & & 0,5 & 0,2 & $12-16$ \\
\hline Abudeduf sp. & Damselfishes & Gemutu & Lerekbatu & 0,3 & 0,1 & $8-12$ \\
\hline Loligo sp. & Squid Great Baracuda & Cumi-cumi & Cumi-cumi & 0,8 & 0,3 & $10-14$ \\
\hline Sepia spp. & Cuttlefish & Sotong & Sotong & 0,6 & 0,2 & $8-14$ \\
\hline Jumlah & & & & 286 & 100,0 & \\
\hline
\end{tabular}


Tabel 10 Komposisi dan modus panjang ikan hasil tangkapan setnet tanggal 1 Desember 2012

\begin{tabular}{|c|c|c|c|c|c|c|}
\hline Nama IImiah & Nama FAO & $\begin{array}{c}\text { Nama } \\
\text { Indonesia }\end{array}$ & Nama Lokal & $\begin{array}{l}\text { Berat } \\
(\mathrm{Kg})\end{array}$ & $\%$ & $\begin{array}{c}\text { Panj.Total } \\
\text { ( cm ) }\end{array}$ \\
\hline Selaroides leptolepis & Yellow stripe trevally & Selar kuning & Bui-bui & 1 & 0,3 & $30-40$ \\
\hline Hemirhamphus sp. & Barred Garfish & Julung-julung & Jerulak & 1 & 0,3 & $35-50$ \\
\hline Scomberomorus commersoni & Barred Spanish & Tenggiri & Tinombo & 60 & 18,9 & $80-120$ \\
\hline Trichiurus lepturus & Hair Tail & Layur & Layur & 30 & 9,5 & $54-90$ \\
\hline Sphyraena jello & Banded Barracuda & Alu-alu & Loli-Ioli & 80 & 25,2 & $19-26$ \\
\hline Atule mate & & Selar & & 2 & 0,6 & $12-18$ \\
\hline Rastrelliger kanagurta & Stripped Mackerel & Kembung Lelaki & Kombong & 10 & 3,2 & $24-30$ \\
\hline Chorinemus tol & Slender leatherskin & Talang-talang & Pace-pace & 5 & 1,6 & $27-36$ \\
\hline Megalaspis cordylla & Hardtail scad & Tetengkek & Sarisi & 10 & 3,2 & $23-32$ \\
\hline Chirocentrus dorab & Wolf herring & Parang-parang & Bale-bale & 4 & 1,3 & $60-75$ \\
\hline Sardinella sirm & Spotted Sardinella & Siro & & 3 & 0,9 & $20-30$ \\
\hline Scomberomorus guttatus & Spotted Spanish & Tenggiri papan & & 15 & 4,7 & $25-35$ \\
\hline Loligo sp. & Squid Great Baracuda & Cumi-cumi & Cumi & 3 & 0,9 & $14-20$ \\
\hline Leiognathus sp. & Ponyfish & Petek & Oco-oco & 15 & 4,7 & $12-20$ \\
\hline Dussumieria acuta & Round Herring & Japuh & Tembang jawa & 0,5 & 0,2 & $18-28$ \\
\hline Sphyraena barracuda & Great Barracuda & Barakuda & Pangkalasan & 15 & 4,7 & $36-45$ \\
\hline Elagastis bippinulatus & Rainbow runner & Sunglir & Rapo-rapo & 0,5 & 0,2 & $14-16$ \\
\hline Mene maculata & Moon Fishes & Petek Semar & Petek Cerameng & 0,8 & 0,3 & $13-22$ \\
\hline Leiognathus equulus & Yellowspot Ponyfish & Petek & Bete-bete & 2 & 0,6 & $10-16$ \\
\hline Upeneus sulphureus & Yellow Goatfish & Kuniran & Ciko & 0,8 & 0,3 & $12-18$ \\
\hline Abudeduf sp. & Damselfishes & & Lerek Batu & 0,5 & 0,2 & $8-12$ \\
\hline Formio niger & Black Pompret & Bawal Hitam & Menrimasang & 5 & 1,6 & $44-48$ \\
\hline Sepia spp. & Cuttlefish & Sotong & Sotong & 1 & 0,3 & $10-14$ \\
\hline Alectis indicus & Threadfin Trevally & Kuwe & Rambo-rambo & 0,8 & 0,3 & $12-15$ \\
\hline Carangoides malabaricus & Trevally & Kuwe & Cirakmata & 0,5 & 0,2 & $12-18$ \\
\hline Sardinella longiceps & Indian Oil Sardinella & Lemuru & Sibula & 0,5 & 0,2 & $14-20$ \\
\hline Tylosorus crocodyllus & Gar Fish & Cendro & Penru & 40 & 12,6 & $35-50$ \\
\hline Gerres oyena & Common Mojarra & Putihan & Brangkas & 0,5 & 0,2 & $14-18$ \\
\hline \multirow[t]{2}{*}{ Sphyraena barracuda } & Great Barracuda & Barakuda & Menggila & 10 & 3,2 & $18-35$ \\
\hline & & & & 317,4 & 100,0 & \\
\hline
\end{tabular}

Tabel 11 Hasil tangkapanan setnet yang digunakan untuk pakan karamba apung di laut

\begin{tabular}{lll}
\hline Famili & $:$ Mullidae \\
Genus & $:$ Upeneus \\
Species & $:$ Upeneus sulphureus \\
Nama Indonesia Nama & $:$ Kuniran \\
Lokal English Name & $:$ CikoYellow Goatfish \\
Kisaran TL & $:$ Sphyraenidae \\
\hline Famili & $:$ Sphraena \\
Genus & $:$ Sphyraena barracuda \\
Species & $:$ Alu-alu/Baracuda \\
Nama Indonesia Nama & $:$ Barracuda \\
Lokal English Name & $:$ 30-120 cm \\
Kisaran TL & $:$ Leiognathidae \\
& $:$ Leiognathus \\
Famili & $:$ Leiognathus sp. \\
Genus & $:$ Petek, Oco-oco \\
Species & $:$ Yellowspot Ponyfish \\
Nama Indonesia Nama & $:$ Tylosuridae \\
Lokal English Name & $:$ Tylosurus \\
Kisaran TL & $:$ Tylosurus crocodyllus \\
\hline Famili & $:$ Cendro \\
Genus & $:$ TenruGarfish \\
Species & No-80 cm \\
Nama Indonesia Nama & \\
Lokal English Name & Kisaran TL & \\
\hline
\end{tabular}




\section{KESIMPULAN}

Kegiatan pendampingan bidang teknis dan manajemen selama kaji terap setnet di Jeneponto telah menjaga keberlanjutan pengelolaan perikanan setnet. Pembinaan bidang teknis dengan konsultansi meliputi: perawatan unit setnet termasuk pencucian dan perbaikan jaring setnet, penyediaan bahan dan petunjuk pembuatan komponen setnet, keselamatan kerja, pengamatan dalam air terhadap kondisi setnet dengan penyelaman, identifikasi dan penamaan ikan, penanganan ikan dengan berbagai bentuk pengolahan untuk konsumsi: pangan, pakan, budi daya induk dan pembesaran, dan penyelamatan hewan air yang dilindungi.

Pembinaan bidang manajemen mengenai kesadaran berdisiplin melakukan pengoperasian dan perawatan unit setnet, sistem pendayagunaan bagi hasil, tata kelola keuangan perikanan setnet, serta motivasi kerja menambah pendapatan dan tanggung jawab terhadap lingkungan di sekitar pengoperasian setnet sehingga terbukti kelompok nelayan masih kompak bersemangat mengoperasikan setnet sejak 2009.

Peningkatan kinerja alat melalui pengadaan cadangan komponen unit penaju, unit serambi dan slope, dan penguatan unit kerangka setnet sehingga terjadi peningkatan jumlah hari pengoperasian dan kecenderungan ikan lebih banyak memasuki kantong baru.

Capaian kinerja operasional setnet adalah jumlah hari kerja periode JanuariNovember 2012 sebanyak 135 kali hari operasi dengan total hasil tangkapan 25 ton senilai 158,9 juta rupiah dengan rata-rata $185 \mathrm{~kg} / \mathrm{hari}$ atau senilai 1,18 juta rupiah/hari.

Kinerja setnet yang lebih baik dengan desain dan konstruksi yang dilengkapi komponen cadangan unit setnet dan kelengkapan bahan dan peralatan untuk perawatan menjadi bahan skema pengembangan setnet di beberapa lokasi lainnya.

\section{DAFTAR PUSTAKA}

Fukahori K. 1992. The Management of Setnet Fishing. Kanagawa International Fisheries Training Center, Japan.

Inoue Y, Arimoto T. 1987. Acoustic Survey on Salmon Behavior in Relation to the Capturing Process of the Setnet. International Symposium on Fisheries Acoustics Juni 22-26, 1987, Seatle, Washington, USA.

Martasuganda S. 2005. Setnet (Teichi Ami). Buku. IPB. Bogor.

Matsomoto K. 1991. The Plan and operation of Setnet. Teaching Material for Coastal Fishing Technology Course 1991. Kanagawa International Fisheries Training Centre, JICA, Japan.

Matsunaga Y. 1990. Setnet Fisheries Southeast asian Fisheries Development Center. SEAFDEC, TD, Samutprakhan, Thailand.

Yoshikawa A et al. 1974. Primary Investigation The Bottom for Installation of Setnet in Coastal Water of Peru. Interim Report.

Zarochman, Arimoto T, Baskoro MS. 1995. Setnet Fishery Pursuant to Review on Catches of Setnet and Fish Behavior in Fishing Ground. Journal ARIOMMA as the Information Media of Marine Resources. Vol. 1., Fishing Technology Development Center Semarang.

Zarochman, Widodo. 2010. Kerekayasaan Perikanan Setnet Perairan Dangkal. Program Dokumen, PD/PSN/1/2010. BBPPI Semarang, Direktorat Jenderal Perikanan Tangkap Kementrian Kelautan dan Perikanan. Desember 2011.

Zarochman, Purnomo A, Fakhrudin. 2012. Laporan pendampingan uji coba pengembangan setnet di Jeneponto 2012. BBPPI Semarang, Direktorat Jenderal Perikanan Tangkap Kementrian Kelautan dan Perikanan. Desember 2012. 